nall at APSA. The 1995 competition will be announced in the December issue of $P S$.

\section{Advisory Opinion from Ethics Committee on Notification of Job Applicants When Positions Are Filled}

The APSA Committee on Professional Ethics, Rights and Freedoms has issued an Advisory Opinion stating that it is good professional practice to notify job applicants when a position has been filled. This statement will be added to APSA's Open Listing Policy regarding announcement of job openings. The Open Listing Policy is part of the APSA Guide to Professional Ethics in Political Science and it is printed in each issue of the Personnel Service Newsletter.

The policy, with the new statement italicized for emphasis, is as follows:

\section{Open Listing Policy.}

It is a professional obligation of all political science departments to list in the APSA Personnel Service Newsletter all positions for which they are recruiting at the Instructor, Assistant, and Associate Professor levels. In addition, the listing of openings at the Full Professor level are strongly encouraged. It is also a professional obligation for departments to list temporary and visiting positions. Good professional practice and courtesy also calls for applicants to be notified when a position is filled.

The Committee on Professional Ethics, Rights and Freedoms is chaired by John J. DiIulio of the Woodrow Wilson School, Princeton University. Other current members are Jean Elshtain, Vanderbilt University, Joseph Silver, University System of Georgia, Janna Merrick, University of South Florida,

Michael E. Brint, Kenyon College, and Robert Montjoy, Auburn University. Contact Michael Brintnall at APSA with questions about the above policy or the work of the Committee on Professional Ethics, Rights and Freedoms.

\section{APSA Organized Section News}

Last spring, the organized section on Applied Political Science conducted a mail survey of section members and potential members concerning how their interests can best be served within the Association. While there was considerable support for remaining a separate section rather than disbanding or merging with a related section (the favorite for this alternative was Public Policy), this will not be possible under rules adopted by the Council in 1993 unless the membership increases to at least 250 (or about double the current level) before the spring of 1995. Applied political scientists, currently nonmembers of the section, are encouraged to join before December 31,1994 . They may do so by submitting $\$ 5$ to the APSA, c/o Michael Brintnall, 1527 New Hampshire Ave., N.W., Washington, D.C. 20036. For further information, please contact the section head, Bill Bacchus, Room 3726 N.S., U.S. Agency for International Development, Washington, D.C. 20523; 202-736-4014 (fax: call first); or the Treasurer, Howard Silver, COSSA, 1522 K St. N.W., Washington, D.C. 20036; 202-842-3525 (fax 202-842-2788).

\section{Verba Appoints Katzenstein and Katzenstein 1995 Program Chairs}

APSA President-Elect Sidney Verba, Harvard University, has appointed Mary Fainsod Katzenstein and Peter J. Katzenstein, Cornell University, to be the 1995 program chairs. The 1995 annual meeting will be held at the Chicago Hilton and Towers, August 31 through September 3, 1995, in Chicago, Illinois.

Katzenstein and Katzenstein have selected as their theme for the 1995 meeting "Liberalism at Century's End: Competing Perspectives." The relationship between the theme and the program's 46 divisions is described in the "Call

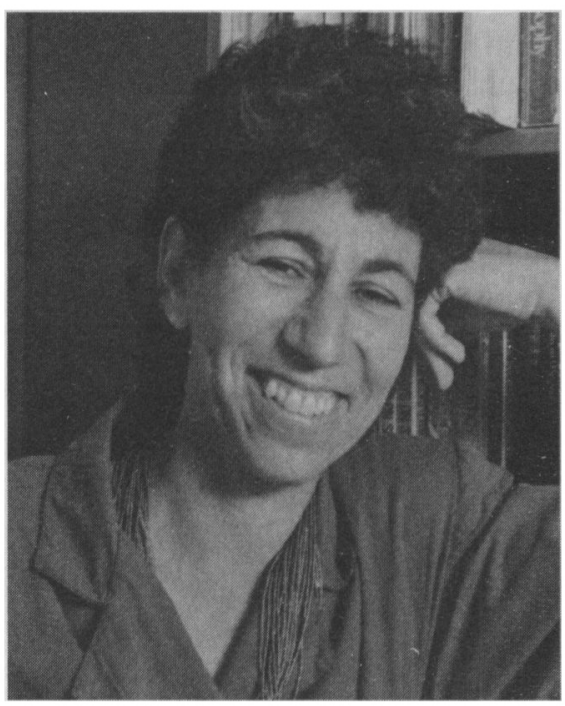

Mary Fainsod Katzenstein

for Papers" appearing elsewhere in this issue of $P S$.

Katzenstein and Katzenstein encourage wide participation in the 1995 program. The program chairs have introduced a new approach to organizing the program, recognizing the increasing size and complexity of the annual meeting. The chairs have developed submission forms for paper, panel, and roundtable proposals. The forms and detailed participation guidelines appear in this issue of $P S$. Please copy and use the forms when submitting proposals to division chairs.

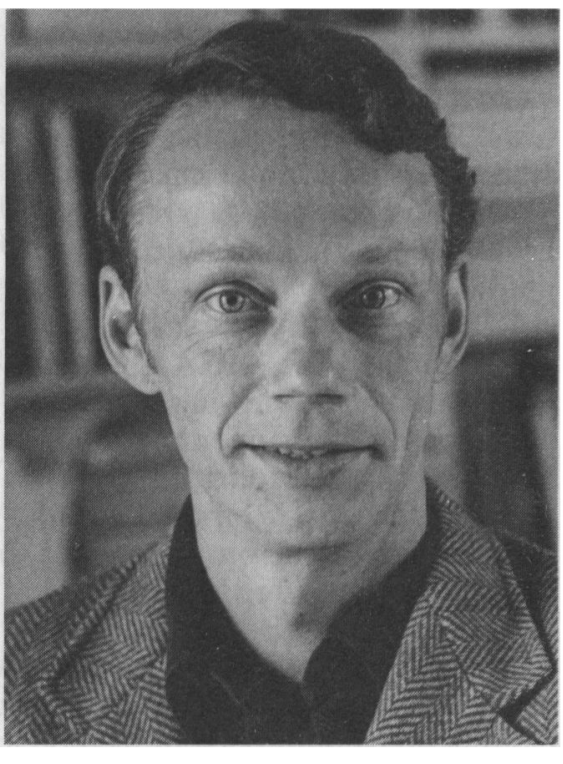

Peter J. Katzenstein

(Photo by Charles Harrington) 